Received on 22 November, 2012; received in revised form, 11 January, 2013; accepted, 23 February, 2013

\title{
STABILITY INDICATING HPLC METHOD FOR THE DETERMINATION OF CANDESARTAN IN PHARMACEUTICAL DOSAGES FORM
}

Sachin Bhagwate*, N. J. Gaikwad and Pawan Tarte

Department of Pharmaceutical Sciences, Rashtrasant Tukadoji Maharaj Nagpur University Nagpur 440 033, Maharashtra, India

Keywords:

Candeartan, HPLC, Validation, Stability, Degradation

Correspondence to Author:

Sachin Bhagwate (Senior Research Fellow)

c/o Dr. N. J. Gaikwad, Professor, Department of Pharmaceutical Sciences, Rashtrasant Tukadoji Maharaj Nagpur University, Nagpur440 033, Maharashtra, India

E-mail: s.bhagwate@gmail.com
ABSTRACT: Candesartan was degraded together under different stress test conditions prescribed by International Conference on Harmonization. The samples so generated were used to develop a stability-indicating high performance liquid chromatographic (HPLC) method for the candesartan. The drug was well separated from degradation products using a reversedphase (C-18) column and a mobile phase comprising of Acetonitrile: Buffer (80:20 v/v) at $\mathrm{pH}$ - 3. Other HPLC parameters were: flow rate, $1 \mathrm{~mL} / \mathrm{min}$; detection wavelength, $225 \mathrm{~nm}$; and injection volume $20 \mu \mathrm{l}$. The method was validated for linearity, precision, accuracy etc. Results obtained after validation study, indicating that the proposed single method allowed analysis of Candesartan, in the presence of their degradation products formed under a variety of stress conditions. The developed procedure was also applicable to the determination of stability of the drug in commercial pharmaceutical dosage form.
INTRODUCTION: Candesartan is an angiotensin II receptor antagonist ${ }^{1}$ used mainly for the treatment of hypertension. Chemically Candesartan is, 2-Ethoxy-1[[2I-(1H-tetrazol-5-yl)[1,1l-biphenyl)-4-yl]methyl]-1Hbenzimidazole-7-carbox-ylate, 1-[[(cyclohexyloxy) carbonyl] oxy] ethylester. The structure of Candesartan is shown in figure 1.

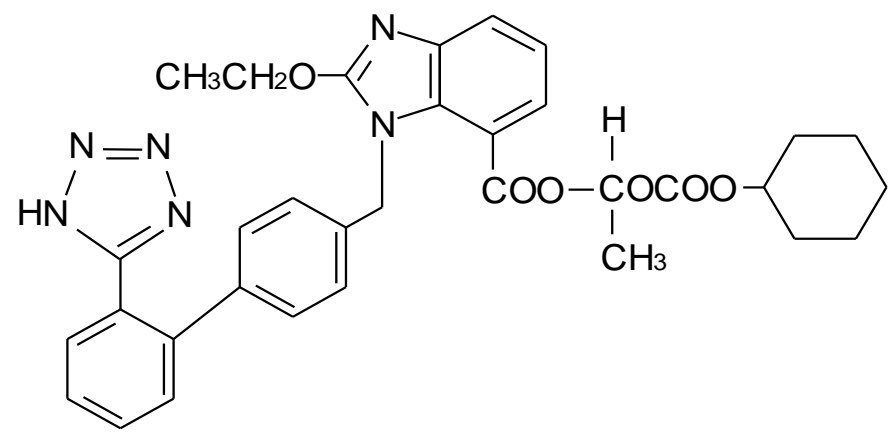

FIGURE 1: STRUCTURE OF CANDESARTAN
There are few analytical methods are available for its estimation in biological fluids includes HPLC with fluorometric detection and with UV detection ${ }^{2,3}$.

The aim of the present study was to develop an accurate, precise, specific, reproducible and stability indicating HPLC method for the estimation Candesartan. The Candesartan was purposely degraded by acid, base, oxide, dry heat, wet heat and UV light treatment to check the stability and to develop stability indicating assay method ${ }^{4-6}$. The developed analytical method was validated by means of linearity, accuracy, precision, LOD, LOQ, ruggedness and robustness as per International Conference on Harmonization $(\mathrm{ICH})$ guidelines ${ }^{7-8}$.

MATERIALS AND METHODS: Candesartan was supplied by Dr. Reddy's Laboratory, Hyderabad. All the chemicals used during the study were of AR / HPLC / GC grades and procured from Merck, Mumbai, 
Qualigens, Mumbai, Rankem, New Delhi, etc. Millipore membrane filters $(0.45 \mu)$ were used for filtration of mobile phase and working solutions. Double distilled water and the volumetric glasswares of class ' $A$ ' grade were used throughout the experimental work.

Shimadzu HPLC system consists of following components: Shimadzu HPLC pump LC-10ATvp, On Line Degasser DGU-14A, Low pressure Gradient flow control unit FCV-10ALvp, Rheodyne injector 7725 I with $20 \mu \mathrm{l}$ loop, Column oven CTO-10ASvp, UV-VIS detector SPD10AVp with SHIMADZU class CSW software, Column Thermo Hypersil ODS $5 \mu \mathrm{C} 18(150 \times 4.6 \mathrm{~mm})$

\section{Forced Degradation of Candesartan}

1. Acid induced degradation: The $50 \mathrm{mg}$ of Candesartan was dissolved in $20 \mathrm{~mL}$ of methanol; $5 \mathrm{~mL}$ of $1 \mathrm{~N}$ Hydrochloric acid $(\mathrm{HCl})$ was added. The solution was refluxed for $6.0 \mathrm{~h}$ at $96-98^{\circ} \mathrm{C}$ on boiling water bath. After cooling at room temperature acid was neutralized with $1 \mathrm{~N} \mathrm{NaOH}$ then volume was completed up to 50 $\mathrm{mL}$ with methanol to obtain concentration 1.0 $\mathrm{mg} / \mathrm{mL}$.

2. Base induced degradation: The $50 \mathrm{mg}$ of Candesartan was dissolved in $20 \mathrm{~mL}$ of methanol; $5 \mathrm{~mL}$ of $1 \mathrm{~N} \mathrm{NaOH}$ was added. The solution was refluxed for $6.0 \mathrm{~h}$ at $96-98^{\circ} \mathrm{C}$ on boiling water bath. After cooling at room temperature base was neutralized with $1 \mathrm{~N} \mathrm{HCl}$ then volume was completed up to $50 \mathrm{~mL}$ with methanol to obtain concentration $1.0 \mathrm{mg} / \mathrm{mL}$.

3. Hydrogen peroxide induced degradation: The $50 \mathrm{mg}$ of Candesartan was dissolved in $20 \mathrm{~mL}$ of methanol; $5 \mathrm{~mL}$ of $30 \%$ Hydrogen peroxide was added. The solution was kept for $6.0 \mathrm{~h}$ in dark at room temperature then the volume was completed up to $50 \mathrm{~mL}$ with methanol to obtain concentration $1.0 \mathrm{mg} / \mathrm{mL}$. $6.0 \mathrm{~h}$ in dark at room temperature then the volume was completed up to $50 \mathrm{~mL}$ with methanol to obtain concentration $1.0 \mathrm{mg} / \mathrm{mL}$.

4. Wet heat degradation: The $50 \mathrm{mg}$ of Candesartan was dissolved in $20 \mathrm{~mL}$ of methanol; $5 \mathrm{~mL}$ of water was added. The solution was refluxed for $6.0 \mathrm{~h}$ at $96-98^{\circ} \mathrm{C}$ on boiling water bath. After cooling at room temperature the volume was completed up to $50 \mathrm{~mL}$ with methanol to obtain concentration $1.0 \mathrm{mg} / \mathrm{mL}$.

5. Dry heat degradation: The Candesartan was kept in oven at 110 o $\mathrm{C}$ for $12 \mathrm{~h}, 50 \mathrm{mg}$ of drug was weighed and dissolved in methanol to obtain concentration $1.0 \mathrm{mg} / \mathrm{mL}$ to study dry heat degradation.

6. Photochemical degradation: The Candesartan drug was kept in sun light for $30 \mathrm{~h}$ (cumulative), $50 \mathrm{mg}$ of drug was weighed and dissolved in methanol to obtain concentration $1.0 \mathrm{mg} / \mathrm{mL}$ to study photochemical degradation.

All six degraded samples solutions of concentration of $1 \mathrm{mg} / \mathrm{mL}$ from the solution $5 \mathrm{~mL}$ was pipette out and diluted up to $10 \mathrm{~mL}$ with methanol to obtain $500 \mu \mathrm{g} / \mathrm{mL}$, from the solution $5 \mathrm{~mL}$ was pipette out and diluted up to $25 \mathrm{~mL}$ with mobile phase to obtain concentration $100 \mu \mathrm{g} / \mathrm{mL}$ which was used for degradation study.

Development of HPLC method: HPLC studies were carried out on all the reaction solutions individually, and on a mixture of the solutions in which decomposition was observed. The separations were achieved by gradient elution using Acetonitrile: Buffer (80:20 v/v)[ Buffer pH- 3 (Buffer Preparation - $4.0 \mathrm{~mL}$ Ortho-Phosphoric Acid was mixed in $1000 \mathrm{~mL}$ of water and $\mathrm{pH}-3$ adjusted with Triethylamine )] as the mobile phase. It was filtered through $0.45 \mu$ membrane filter and degassed before use. The injection volume was 20 $\mu \mathrm{L}$.

The working concentration was $100 \mu \mathrm{g} / \mathrm{mL}$ and mobile phase flow rate was $1 \mathrm{~mL} / \mathrm{min}$ with column oven temperature $30^{\circ} \mathrm{C}$. The detection was carried out at $225 \mathrm{~nm}$. Chromatogram of Candesartan is shown in figure 2. 


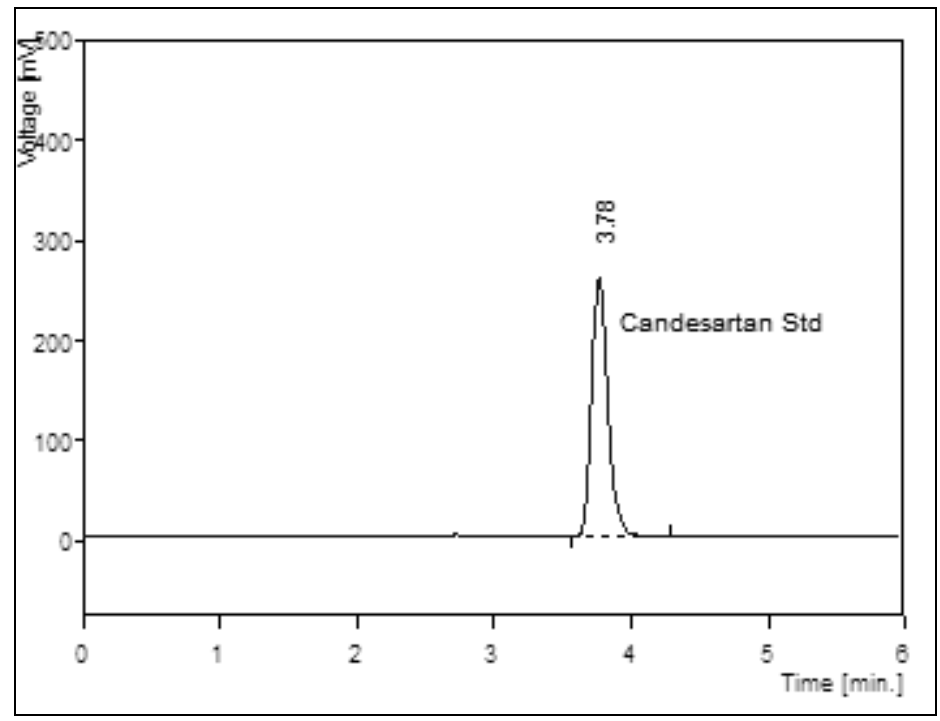

FIGURE 2: CHROMATOGRAM OF CANDESARTAN STANDARD

\section{Validation Parameters}

1. Accuracy: Accuracy of proposed method was ascertained on the basis of recovery studies performed by standard addition method. In the study standard was added to fixed quantity of tablet powder at different levels of labeled claim (i.e. 60 to $140 \%$ of labeled claim).

2. Precision: Precision of any analytical method was ascertained by replicate estimation of drug in sample of homogeneous tablet powder by different analyst, intraday and interday. The results are expressed as SD and \% RSD of series of measurements.

3. Limit of Quantitation (LOQ): The quantitation limit was determined by the analysis of samples with known concentrations of analyte and by establishing the minimum level at which the analyte can be quantified with acceptable accuracy and precision.

4. Linearity and range: The linearity of analytical method was determined by injecting 50 to 200 $\mu \mathrm{g} / \mathrm{mL}$ of Candesartan and peaks were recorded and plotted graph, concentration versus area response of Candesartan. The range of analytical method was established with a suitable level of precision, accuracy and linearity.
Application of developed method on Marketed Formulation:

Standard Preparation: Accurately weighed quantity of Candesartan $(25 \mathrm{mg}$ ) was dissolved in the methanol and volume was completed up to the $50 \mathrm{~mL}$ to obtain conc $500 \mu \mathrm{g} / \mathrm{mL}, 5 \mathrm{~mL}$ of the solution was diluted up to $25 \mathrm{~mL}$ with mobile phase to obtain conc $100 \mu \mathrm{g} / \mathrm{mL}$.

Sample Preparation: Twenty tablets were weighed and finely powdered. An accurately weighed quantity of tablet powder equivalent to $25 \mathrm{mg}$ of Candesartan was taken into $50 \mathrm{~mL}$ volumetric flask and dissolved in the methanol. It was then sonicated for $10 \mathrm{~min}$ and volume was completed to the mark with the methanol. The solution was filtered through $0.45 \mu$ membrane filter. 5 $\mathrm{mL}$ of the filtered solution diluted to $25 \mathrm{~mL}$ with mobile phase to obtain conc $100 \mu \mathrm{g} / \mathrm{mL}$ of Candesartan. The percent label claim was calculated against the standard.

RESULT AND DISCUSSION: HPLC studies of samples obtained on stress testing of Candesartan under different conditions using Acetonitrile: Buffer (80:20 $\mathrm{v} / \mathrm{v}$ ) as the mobile solvent system suggested the following degradation behavior.

a. Acid induced degradation product: The chromatogram of the acid degraded sample for Candesartan showed additional peak at RT 1.77 min and RT 2.73 min (figure 3 ) indicating that Candesartan undergoes degradation under acidic condition.

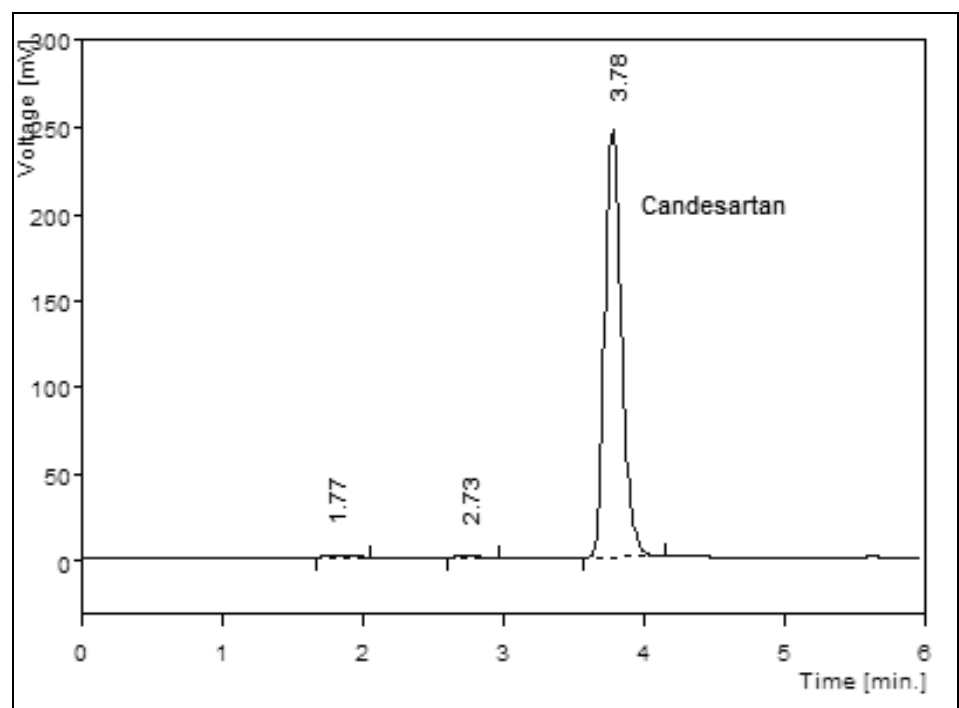

FIGURE 3: CHROMATOGRAM OF CANDESARTAN AND ITS ACID DEGRADATION PRODUCTS 
b. Base induced degradation product: The chromatogram of the base degraded sample for Candesartan showed additional peak at RT 1.77 min, RT $2.73 \mathrm{~min}$ and RT $5.64 \mathrm{~min}$ (figure 4) indicating that Candesartan undergoes degradation under basic condition.

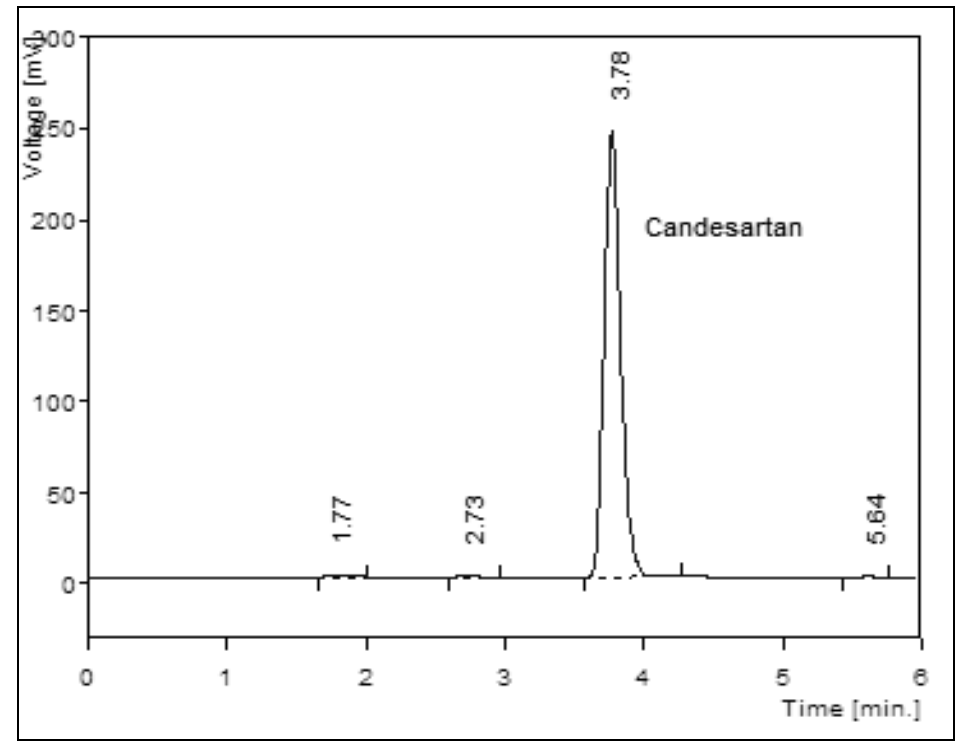

FIGURE 4: CHROMATOGRAM OF CANDESARTAN AND ITS BASE DEGRADATION PRODUCTS

c. Hydrogen peroxide induced degradation product: The chromatogram of the Hydrogen peroxide degraded sample for Candesartan showed additional peak at RT $1.77 \mathrm{~min}$ and RT $2.73 \mathrm{~min}$ (figure 5) indicating that Candesartan undergoes degradation under hydrogen peroxide condition.

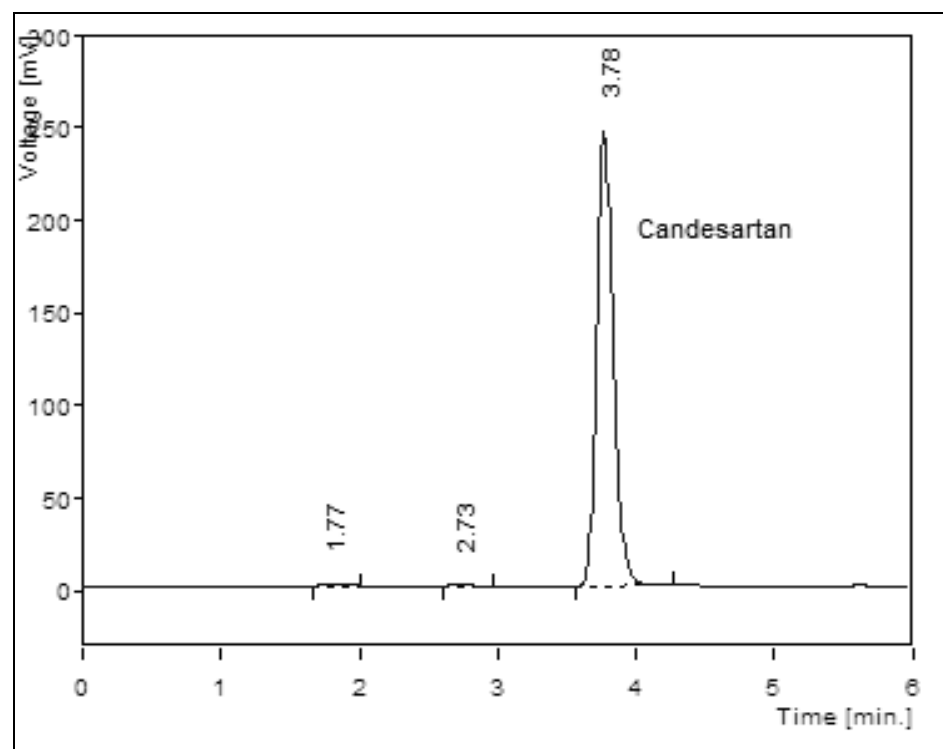

FIGURE 5: CHROMATOGRAM OF CANDESARTAN AND ITS OXIDE DEGRADATION PRODUCTS d. Wet heat degradation product: The chromatogram of the wet heat degraded sample for Candesartan showed additional peak at RT 1.77 min and RT 2.73 min (figure 6) indicating that Candesartan undergoes degradation under wet heat condition.

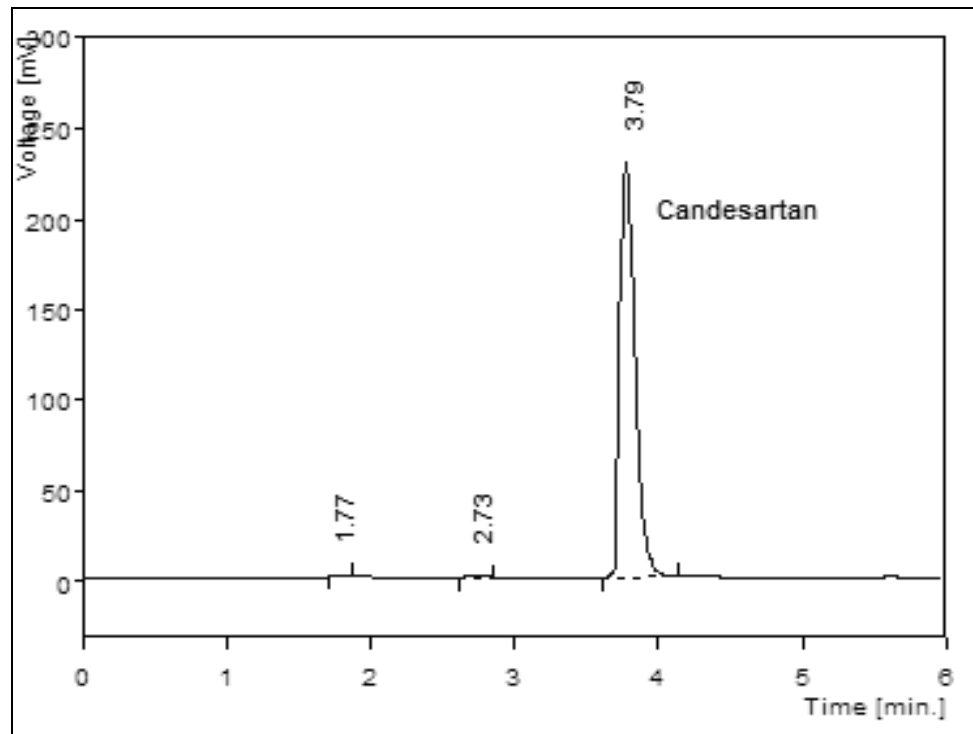

FIGURE 6: CHROMATOGRAM OF CANDESARTAN AND ITS WET HEAT DEGRADATION PRODUCTS

e. Dry heat degradation product: The chromatogram of the dry heat degraded sample for Candesartan showed additional peak at RT 1.77 min (figure 7) indicating that Candesartan undergoes degradation under dry heat condition.

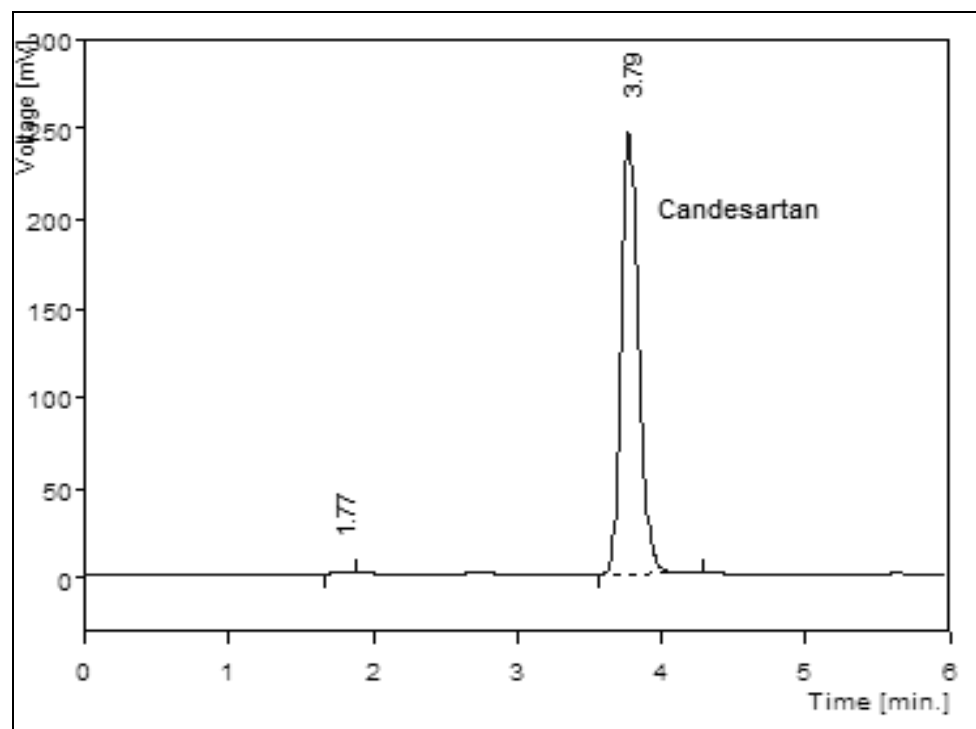

FIGURE 7: CHROMATOGRAM OF CANDESARTAN AND ITS DRY HEAT DEGRADATION PRODUCTS 
f. Photochemical degradation product: The chromatogram of the photochemical degraded sample for Candesartan showed additional peak at RT $1.78 \mathrm{~min}$ and RT $2.73 \mathrm{~min}$ (figure 8) indicating that Candesartan undergoes degradation under photochemical exposure.

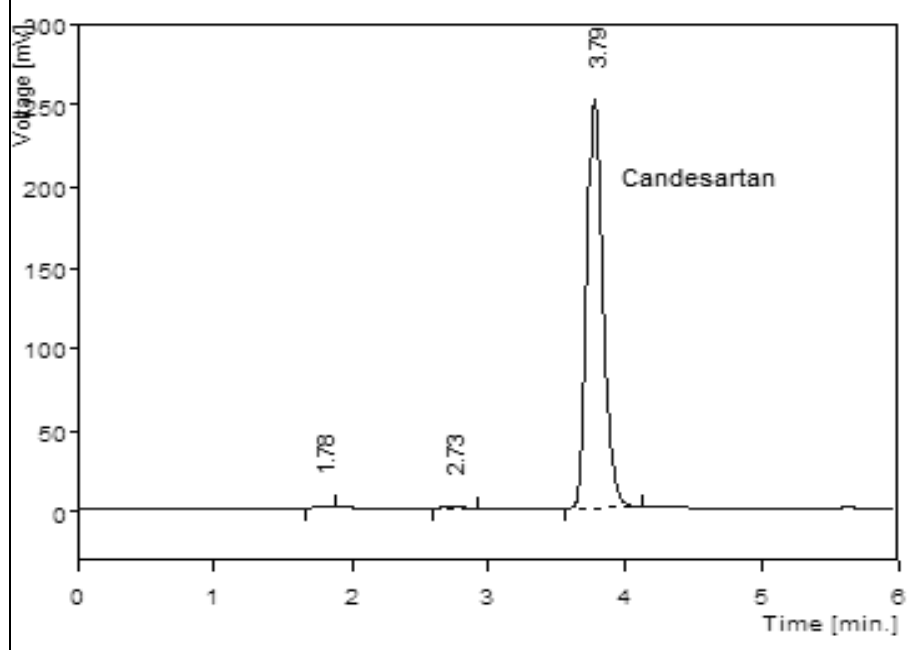

FIGURE 8: CHROMATOGRAM OF CANDESARTAN AND ITS PHOTO DEGRADATION PRODUCTS
The results of forced degradation study are shown in Table 1.

\section{Method Validation:}

1. Accuracy: The HPLC area responses for accuracy determination are depicted in Table 2. Good recoveries (100.41-101.46\%) of the spiked drug were obtained at each added concentration, indicating that the method was accurate.

2. Precision: Results of precision study are shown in Table 3 and 4. The values of SD or RSD under different conditions are within the prescribed limit of $2 \%$, showing high precision of the method.

TABLE 1: RESULTS OF DEGRADATION STUDY

\begin{tabular}{|c|c|c|c|c|c|}
\hline \multirow{2}{*}{ Sr. No. } & \multirow{2}{*}{ Treatment } & \multirow{2}{*}{$\begin{array}{l}\text { Time } \\
\text { (h) }\end{array}$} & \multicolumn{2}{|c|}{$\%$ of Candesartan* } & \multirow{2}{*}{$\%$ of Degradation* } \\
\hline & & & Assay & \pm SD & \\
\hline 1. & $\begin{array}{l}\text { Refluxed with } 5 \mathrm{~mL} \text { of } 1 \mathrm{~N} \mathrm{HCl} \\
\text { on boiling water bath }\end{array}$ & 6 & 94.75 & 0.5462 & 5.25 \\
\hline 2. & $\begin{array}{c}\text { Refluxed with } 5 \mathrm{~mL} \text { of } 1 \mathrm{~N} \mathrm{NaOH} \\
\text { on boiling water bath }\end{array}$ & 6 & 92.78 & 0.4562 & 7.22 \\
\hline 3. & $\begin{array}{l}\text { Stored with } 5 \mathrm{~mL} \text { of } 30 \% \mathrm{H}_{2} \mathrm{O}_{2} \\
\text { in dark at room temperature }\end{array}$ & 6 & 91.45 & 0.8526 & 8.55 \\
\hline 4. & $\begin{array}{l}\text { Refluxed with } 5 \mathrm{~mL} \text { water } \\
\text { on boiling water bath }\end{array}$ & 6 & 97.15 & 0.4754 & 2.85 \\
\hline 5. & Dry Heat $120^{\circ} \mathrm{C}$ & 12 & 98.45 & 0.7565 & 1.55 \\
\hline 6. & Photo degradation & 30 & 97.15 & 0.2548 & 2.85 \\
\hline
\end{tabular}

* Each value is mean of five observations

TABLE 2: RESULTS OF RECOVERY STUDY

\begin{tabular}{|c|c|c|c|c|c|}
\hline \multicolumn{6}{|c|}{ Candelong Tablet (Avg Wt $280.52 \mathrm{mg}$ for $16 \mathrm{mg}$ of Candesartan ) } \\
\hline Sr. No. & Wt. of Tablet (mg) & Amount of Pure drug added (mg) & Peak area of standard & Peak area of sample & \% Recovery* \\
\hline 1 & 219.46 & 2.5 & 2060.39 & 1245.52 & 100.89 \\
\hline 2 & 218.56 & 7.5 & 2060.39 & 1659.54 & 100.41 \\
\hline 3 & 218.45 & 12.5 & 2060.39 & 2085.56 & 100.89 \\
\hline 4 & 219.48 & 17.5 & 2060.39 & 2498.85 & 101.21 \\
\hline \multirow[t]{4}{*}{5} & 220.45 & 22.5 & 2060.39 & 2909.45 & 101.46 \\
\hline & & & & Mean & 100.97 \\
\hline & & & & $\pm S . D$. & 0.3962 \\
\hline & & & & R.S.D. & 0.3924 \\
\hline
\end{tabular}

* Each value is mean of five observations 
TABLE 3: RESULTS OF PRECISION STUDY (DIFFERENT ANALYST)

\begin{tabular}{ccc}
\hline Sr. No. & Different analyst & $\begin{array}{c}\text { \% Drug estimation* } \\
\text { Candelong }\end{array}$ \\
\hline 1 & I & 99.25 \\
2 & II & 101.36 \\
3 & III & 100.96 \\
& Mean & 100.52 \\
& \pm S.D. & 1.1207 \\
& R.S.D. & 1.1149 \\
\hline
\end{tabular}

* Each value is mean of five observations

TABLE 4: RESULTS OF PRECISION STUDIES (INTRADAY AND INTERDAY)

\begin{tabular}{cccc}
\hline \multirow{2}{*}{ Sr. No. } & \multirow{2}{*}{ Particular } & \multicolumn{2}{c}{$\begin{array}{c}\text { Drug Estimation* } \\
\text { Candelong }\end{array}$} \\
\cline { 3 - 4 } & & Intraday & Interday \\
\hline 1 & I & 99.56 & 100.12 \\
2 & II & 98.99 & 100.85 \\
& Mean & 99.28 & 100.49 \\
& \pm S.D. & 0.4031 & 0.5162 \\
& R.S.D. & 0.4060 & 0.5378 \\
\hline
\end{tabular}

* Each value is mean of five observations

3. Limit of quantitation: Developed method stability indicating method was able to determine $15 \mu \mathrm{g} / \mathrm{mL}$ minimum level concentration of candesartan with high accuracy and precision.

4. Linearity and range: The response for the drug was linear $(r 2=0.9990)$ in the concentration range between $60-140 \mu \mathrm{g} / \mathrm{mL}$.
Application of developed method on marketed formulation: The developed HPLC method is suitable for estimation of Candesartan as it extracts the drug from formulation and determines the percent content with good \%RSD. The results of the application of developed method are shown in Table 5.

TABLE 5: RESULTS OF ESTIMATION OF CANDESARTAN IN TABLETS

\begin{tabular}{|c|c|c|c|c|}
\hline \multicolumn{5}{|c|}{ Candelong (Avg Wt $280.52 \mathrm{mg}$ for $16 \mathrm{mg}$ of Candesartan) } \\
\hline Sr. No. & Weight of Sample (mg) & Peak area of standard & Peak area of sample & \% Drug Estimation* \\
\hline 1 & 438.64 & 2060.39 & 2055.56 & 99.69 \\
\hline 2 & 445.65 & 2060.39 & 2102.22 & 100.35 \\
\hline 3 & 441.25 & 2060.39 & 2056.36 & 99.14 \\
\hline 4 & 440.25 & 2060.39 & 2045.45 & 98.84 \\
\hline \multirow[t]{4}{*}{5} & 442.56 & 2060.39 & 2105.54 & 101.21 \\
\hline & & & Mean & 99.85 \\
\hline & & & $\pm S . D$. & 0.9559 \\
\hline & & & R.S.D. & 0.9574 \\
\hline
\end{tabular}

* Each value is mean of five observations

CONCLUSION: The developed HPLC technique is precise, specific, accurate and stability indicating. The developed method was validated based on $\mathrm{ICH}$ guidelines. Statistical analysis proves that the method is repeatable and selective for the analysis of Candesartan as bulk drug and in pharmaceutical formulations. The method can be used to determine the purity of the drug available from the various sources by detecting the related impurities.
It may be extended to study the degradation kinetics of Candesartan and for estimation of pure and its metabolites in plasma and other biological fluids.

ACKNOWLEDGMENT: The authors are grateful to Dr. Reddy's Laboratories, Hyderabad for providing the gift sample of Candesartan and to the Department of Pharmaceutical Sciences RTM Nagpur University for providing the research facility. 


\section{REFERENCES:}

1. Reynolds, J.E.F and Prasad B.A., IN; Martinadale, the Complete Drug Reference, $33^{\text {rd }}$ Edn, Pharmaceutical Press, London, 2002, pp 853.

2. Helene Stenhoff, Olof Lagerström, Cathrine Andersen: Determination of candesartan and a metabolite in human plasma and urine by liquid chromatography and fluorometric detection. J Chromatogr B 1999; 731(2): 411-417.

3. Peepliwal AK, Bonde CG, Mohanraj K: Bioanalytical Method Development and its Validation for Determination of Candesartan cilexetil by High Performance Liquid Chromatography with UV Detection. Acta Pharm Sci 2010, (52), 247-253.

4. Bakshi M. Singh S. HPLC and LC-MS Studies on Stress Degradation Behavior of Tinidazole and Development of a
Validated Specific, Stability Indicating HPLC Assay Method. J Pharm Biomed Anal 2004, 34, 11-18.

5. Kaul N, Agrawal H, Paradkar AR, Mahadik KR: HPTLC Method for Determination of Nevirapine in Pharmaceutical Dosage Form. Talanta 2004, 62, 843-852.

6. Sinha KP, Damle MC, Bothara KG, "A Validated Stability Indicating HPTLC Method for Determination of Aspirin and Clopidogrel Bisulphate in Combined Dosage Form." Eurasian J. Anal. Chem. 2009. 4(2), 152-160.

7. International Conference on Harmonization guidelines Q1A9 (R2) Stability Testing of New Drug and Product, step 5 version, 2003.

8. International Conference on Harmonization guidelines, validation of analytical procedure: Q2A, I.C.H. Harmonized Tripartite Guidelines, 1996.

How to cite this article:

Bhagwate S, Gaikwad NJ and Tarte P: Stability indicating HPLC method for the determination of Candesartan in Pharmaceutical Dosages Form. Int J Pharm Sci Res 2013; 4(3); 1079-1085. 